\title{
The Use of Macromedia Flash Animation to Enhance Students' English Writing Skill at the Seventh Grade of SMP Yapis 1 Fakfak-West Papua
}

\author{
Wa Lisda \\ wlisda.ff@gmail.com \\ Muhammad Asfah Rahman \\ asfah_rahman@yahoo.com \\ Haryanto Atmowardoyo \\ aharyanto fbsunm@yahoo.co.id \\ State University of Makassar, Indonesia
}

\begin{abstract}
This research is conducted to find out: (1) whether the use of Macromedia Flash Animation enhance students' writing skill or not; (2) the students' interest in English writing class using Macromedia flash animation; (3) whether student's interest have relationship to student's writing ability or not. The research employs the quasi-experimental method. The sample consists of 51 students which belongs to two groups; 27 students in the experimental group and 24 students in the control group. The data are collected by writing test (pre-test and post-test) and questionnaire which is analyzed through SPSS 20.0. In conducting the research, the researchers applies Macromedia Flash Animation as the medium to the experimental group while the teacher in the control group uses power point presentation. The research results indicated that Macromedia Flash Animation can enhance students' English writing skill at the seventh-grade students of SMP Yapis 1 Fakfak-West Papua in academic year 2014/2015. Although the mean score of the experimental group is higher than the mean score of the control group, it does not show a significant difference $(73.93>70.33)$. Therefore, based on pair test, the result shows that the mean score of pre-test and post-test in the experimental group are significantly different (55.41-73.93). Moreover, based on the students' response on the questionnaire, it is found that the mean score is 80.15 which was categorized "interested". The Pearson's $r$ for correlation shows that the correlation coefficient between students' interest and students' writing ability is 0.891 , with the sig. ( 2 tailed) value is less than 0.05 indicates that there is a strong, significant and positive correlation between students' interest and students' writing ability. Specifically, the research result indicates that Macromedia flash animation is interesting and effective to enhance students' writing skill.
\end{abstract}

Key words: Macromedia flash animation, writing skill, interest.

\section{INTRODUCTION}

In the context of learning English, writing is more difficult than other skills of English. Writing is a challenging and complex task, requiring mastery not only of grammatical and theoretical devices but also a conceptual and a judgment element (Heaton,1995). 
Therefore, Spark in Weigle (2009) argues that learning to write involves much more than simply learning grammar and vocabulary of the language, or even the rhetorical forms common to academic writing, writing may involve for each discipline, examining the kinds of issues a discipline considers important. Writing is widely admitted as one of the most difficult skills that learners ever do, either in a foreign language or in their native language.

Thus, since writing is important for the students who study English, a greater priority should be given to it. The teacher and students should be aware of the vital role of writing in foreign language learning. To write well the essay, story, or something else, students must know the steps on writing process and aspects of writing. A good mastery on writing can be acquired through a lot of effective training and a considerable amount of time. So far, the teachers of English generally still apply the conventional techniques, verbal method, in the teaching and learning process of writing. It is regarded that the results are still poor. The complexities that the students deal in their writing have appeared for a long time.

Based on the interview to English teacher of the seventh-grade studentsof SMPYapis 1 Fakfak, the researchers got information that students still found difficulties in English writing. The students have low competence of writing skill and not interested in learning process. It is indicated through the following indicators : 1) the students get difficulties in exploring idea for their writing; 2) they get difficulties on producing grammatically correct sentence and vocabulary varieties to express language function; 3) they do not have self-confidence and afraid of doing mistake in writing; 4) their participation in the class is low, they refuse to create their writing and show up in front of the class; 5) they complained that learning writing is very boring and monotonous thing.

These problems are often assumed come from the media and the method used by the teacher in the classroom teaching. Concerning to the problems above, it is suggested to the teacher to choose the suitable media and method in their teaching. The teacher's teaching media and method are two important factors in creating a good atmosphere in the classroom activities and to encourage the students' learning writing skills effectively. The teacher should know how to build the learners' interest during the class, know how to design materials which are easy to be understood by students.

Various media of teaching writing in English have been applied by the teacher such as mind mapping, sequence picture, song, video, movie clip, elearning etc. Some of them are considered effective in teaching writing. One of the media which can be applied in writing is Macromedia flash animation. 
Macromedia flash animation learning method is learning system using software and hardware which serves simplify the process of data in the form of picture, video, photography, graphic, and animation, in collaboration with sound, text, and voice data interactively controlled by computer. It is also providing a kind of quiz that will make the teaching-learning process more attractive than before. That is why Macromedia Flash Animation was chosen to be applied in this research.

Many advantages of using Macromedia Flash Animation in the learning process: teachers can inspire, intrigue and also motivate students. It is also supporting students to increase understanding, interpreting of data easier, presenting data to be more interesting, and getting new information easier. The researchers believes that using Macromedia Flash Animation in teaching writing may be a suggested solution to develop the effectiveness of English learning. It will help the English teacher to presents interesting lesson material as a way to make students be more engaged, feel fun, interactive and encourage to write in English.

\section{LITERATURE REVIEW}

\section{Previous Related Research Findings}

Pun, (2013) conducted the research to analyze the use of multimedia technology in English language teaching in Nepal. The findings of the result show that the non-native speakers of English as language teachers can teach English more efficiently if they use multimedia technology. The result of the research indicated that the utilization of multimedia technology can fully improve the students' thinking and practical language skills.

Kim and Gilman (2008) had made an investigation of the use of multimedia components such as visual text, spoken text, and graphics in a Web-based self-instruction program to increase learners' English vocabulary learning at Myung Middle School in Seoul, South Korea. The findings of their research show that participants learned better when they received "visual text and added graphics" or "visual text, added spoken text, and added graphics" instruction. The results concluded that an effective way to improve learning of English vocabulary is to offer graphics that illustrate what the vocabulary means.

Kayaoglu, et al (2011) conducted a small-scale experimental study about using animations to learn vocabulary in Turkey. The finding of the research show that using multimedia such as animations contribute to students' achievement in vocabulary learning. Multimedia applications can be 
integrated into language classes not as an alternative way but as an additional way to contribute positively to the atmosphere of class and motivation of students.

\section{Some Pertinent Ideas}

\section{Macromedia Flash Animation}

Macromedia flash animation can be used to facilitate the delivery of an abstract concept in its application that uses a computer and projector. Macromedia flash animations is object-oriented program hase a capability in designing vector-based images, to produce animated motion and sound, and can be used as website creator software. With the advantages it has, Macromedia Flash Animation as audiovisual technology, capable of generating new features that can be utilized in education (Macromedia, 2005).

\section{Components of Writing}

In the Extended ESL Composition profile, Jacob et al in Weigle (2009: 115) point out five components in writing. They are content, organization, vocabulary, structure and mechanics. The description of all those components as follows: Related to the scope of the study, the writer takes all of the components of writing as follows:

\section{Content.}

The content of writing should be clear to readers so that the readers can understand the message conveyed and gain information from it. In order to have a good content of writing, its content should be well unified and completed.

\section{Organization.}

Organization refers to the overall structure pieces of writing. The aim of organizing material in writing involve coherence, the order of importance, general to specific, specific to general, chronological order and spatial order of the pattern.

\section{Vocabulary}

One requirement of a good writing always depends on the effective use of words. The effective use of words will always result in good writing both specific and technical writing, the dictionary is very considerable, vocabulary is one of the components of writing. The lack of vocabulary makes it difficult to express the idea. 


\section{Language Use}

Language use in writing description and another form of writing involve correct language and point of grammar. An adequate grammar should be one that is capable of producing grammar.

\section{Mechanics}

Mechanics is the ability to use correctly those conventions peculiars to the written language, e.g. punctuation, spelling. The use of mechanics is due to capitalization, punctuation, and spelling appropriately. This aspect is very important since it leads readers to understand or recognize immediately what the writer means to express definitely.

\section{The Stage of Writing Process}

Good writers go through several steps to produce a piece of writing. Zemach and Rumisek (2008: 3) described six steps of the writing process as the components of the four main steps, namely prewriting, drafting, reviewing and revising and rewriting.

\section{Prewriting}

Step one: choosing the topic. Before you write, your teacher gives you a specific assignment of some ideas of what to write about, if not, choose your topic yourself.

Step two: gather idea. When you have a topic, think about what you will write about the topic.

Step three: organize. Decide which of the ideas you want to use and where you want to use them. Choose which idea to talk about first, which talk about next, and which talk about last.

\section{Drafting}

Step four: write. Write your paragraph or essay from start to finish. Use your notes about your ideas and organization.

\section{Reviewing and revising}

Step five: review structure and content. Check what you have written. Read your writing silently to yourself or aloud, perhaps to a friend. Look for places where you can add more information and check to see if you have any unnecessary information. Ask a classmate to exchange text with you. Your classmate reads your text and you read his or hers. Getting a reader's opinion is a good way to know if your writing is clear and effective. Learning to give opinions about other people's writing helps you to improve your own. 


\section{Rewriting}

Step six: Revising structure and content. Use your ideas on step five to rewrite your text. Make improvement to the structure and content might need to explain something more clearly and add more details. You may even need to change your organization so that your paper is more logical. Together, steps five and six can be called editing.

Proofread. Read your paper again. This time, check your spelling and grammar and think about the words you have chosen to use.

Make final corrections. Check that you have corrected the errors you discovered in steps five and six and make any other changes you want to make. Now your text is finished.

\section{Interest}

When people talk about interest, they will think about our positive response or attitude to something we like, enjoy, and appreciate which make us having a desire to do. To clearly what actually interest means some theorist will define it.

According to Good (1959), interest is a subject-object attitude, concerned with condition involving a perception or idea in attention and a combination of intellectual and feeling curiosity condition by experience. Interest is feeling of desire to know or to learn about something has a positive attitude towards something he/she really likes and enjoys. When talking about interest, we will think about out positive response or attitude to something we like, enjoy, and appreciate which make us having a desire to do.

Therefore, Hornby (2002) defines interest as: (1) Condition or wanting to know or learn about something or somebody; (2) Quality that arouses concern or curiosity, that holds one's attention; and (3) Something with which one concern oneself.

\section{METHOD}

\section{Design and Samples}

This research applied experimental method which focuses on quasiexperimental design. In this experimental design, it required at least two groups, namely experimental and control group as Gay, et al (2006: 257) states that the quasi experimental design provides adequate control of sources of invalidity. The sample in the experimental group consisted of 24 students and the control group consisted of 27 students. They were the seventh-grade students of SMP Yapis 1 Fakfak. Both of two groups were given the same pre-test and post-test. They were also received the same writing material of the descriptive text. The difference here, the experimental 
group was taught using Macromedia Flash Animation while the control group was be taught by the teacher using power point presentation.

\section{Instruments and Procedure}

Two kinds of instruments - writing test and questionnaire were applied in this research. The writing test consisted of pre-test and post-test. Pre-test was administered before the treatment to know the prior knowledge of the students to assess their competence of writing English while post-test was held at the end of the treatment to know the improvement of students' writing skill after the treatment post-test was to find out the writing ability in English language teaching. Both of control group and experimental group were given the same topic of the test in the same length of time about twenty minutes. There were two pictures displayed on the slide and the students were asked to make description text based on the pictures given. In assessing the students' writing, the researchers used the rubric of writing-analytical scoring' by Jacobs et al in Hughes (2008). which covered five aspects of writing: content, organization, vocabulary, language use, and mechanics.

The treatment was conducted for six meetings in the experimental group. There were two topics used in the treatment. The topic entitled 'What do you think' was taught in the meetings 1-3, while the researchers implemented the material entitle ' Do you have a pet?' at the meeting 4-6. Those topics were used in both experimental and control group, and each meeting spends 80 minutes. In the first and fourth meetings, the writing activities focused on the pre-writing stage. Meanwhile, in the second and fifth meetings, the focus was on pre-writing and drafting. All the stages of the writing process were implemented in the third and sixth meetings.

The questionnaire was arranged by using the ACRS (Attention, Confidence, Relevance, and Satisfaction) Keller's instructional development model. The questionnaire was distributed to the students of the experimental group at the end of the treatment to get information about students' interest in the use of Macromedia Flash Animation in the teaching and learning process.

\section{Data Analysis}

To examine the use of Macromedia Flash Animation on students' writing skill, three major statistical procedures were applied: (1) descriptive statistics, including the frequency, descriptive statistic which calculated the mean and standard deviation; (2) Requirements analysis, including reliability test and normality test; and (3) Inferential statistics, including independent test and paired test. Meanwhile to analyze the correlation between students' interest and students' writing ability, descriptive statistics - Bivariate Correlation with Pearson method (Product Moment Pearson) was used. 


\section{RESULTS AND DISCUSSIONS}

\section{The Students' Improvement in Writing Skill by Using Macromedia Flash Animation}

The students' score of pre-test and post-test on each writing component for experimental group

Table 1 is the statistical summary of the students' pre-test and post-test on each writing component assessed on the experimental group. The statistical summary depicted in table 1 below shows that the total number of subjects is 27 students. The score achieved by the students tend to get increased from pre-test to post-test.

Table 1

The Statistical Summary of the Students' Pre-test and Post-test on Each Writing Component Assessed in Experimental Group and Control Group

\begin{tabular}{|c|c|c|c|c|c|c|c|c|}
\hline \multirow{2}{*}{ Components } & \multicolumn{3}{|c|}{ Experimental Group } & \multicolumn{3}{c|}{ Control Group } \\
\cline { 2 - 9 } & \multicolumn{2}{|c|}{ Pretest } & \multicolumn{2}{c|}{ Posttest } & \multicolumn{2}{c|}{ Pretest } & \multicolumn{2}{c|}{ Posttest } \\
\cline { 2 - 8 } & Mean & SD & Mean & SD & Mean & SD & Mean & SD \\
\hline Content & 16.96 & 2.40 & 21.78 & 2.53 & 18.13 & 3.07 & 20.42 & .78 \\
Organization & 12.30 & 2.07 & 15.41 & 1.87 & 14.33 & 2.01 & 14.80 & 1.80 \\
Vocabulary & 11.56 & 1.83 & 15.22 & 1.97 & 13.17 & 2.08 & 14.71 & 2.18 \\
Lang. Use & 11.71 & 2.16 & 17.93 & 3.14 & 11.54 & 2.15 & 16.96 & 2.35 \\
Mechanics & 2.89 & .58 & 3.60 & .75 & 2.96 & .46 & 3.46 & .51 \\
\hline
\end{tabular}

The data in table 1 shows that the comparison of pre-test and post-test on each writing component assessed on experimental group shows that there was a significant difference. It was proved by the statistical summary that the mean score of pre-test was categorized as 'very poor' and 'fair to good' while the mean score of post-test was categorized as 'fair to good' and 'good to average'. The mean score in pre-test on 'content' increased 4.81 points; 'organization' increased 3.11 points; 'vocabulary' aspect was 3.67 points increased; The score of 'language use' aspect increased up to 6.22 points; while the mean score on 'mechanics' aspect increased 0.70 points. It means that overall it indicated that there was a significant difference on experimental group test result in pre-test and post-test.

The control group also shows the difference but it is not so significant. By the statistical summary, the mean score of pre-test was categorized as 'very poor' and 'fair to good' while the mean score of post-test was 
categorized as 'fair to good' and 'good to average'. The point of 'content' on pre-test and post-test was 2.30; The mean score on 'organization' only increased 0.46 points; 'vocabulary' aspect increased 1.54 points; The score of 'language use' aspect increased up to 5.42 points; and 'mechanics' aspect increased 0.50 points; overall components of writing in control group on post-test were higher than post-test although they were not really significant.

The percentage of the students' performance of post-test in experimental and control group

\section{Table 2}

The Rate Percentage and Frequency of the Students' Scores of Post-test in Experimental and Control Group

\begin{tabular}{|c|c|c|c|c|c|c|c|c|c|}
\hline \multirow{2}{*}{$\begin{array}{l}\text { Classifi- } \\
\text { cation }\end{array}$} & \multirow{2}{*}{ Score } & \multicolumn{3}{|c|}{ Experimental Group } & \multicolumn{4}{c|}{ Control Group } \\
\cline { 3 - 10 } & & \multicolumn{2}{|c|}{ Pre-test } & \multicolumn{2}{|c|}{ Post-test } & \multicolumn{2}{c|}{ Pre-test } & \multicolumn{2}{c|}{ Post-test } \\
\cline { 3 - 10 } & $\mathrm{F}$ & $\%$ & $\mathrm{~F}$ & $\%$ & $\mathrm{~F}$ & $\%$ & $\mathrm{~F}$ & $\%$ \\
\hline $\begin{array}{l}\text { Very } \\
\text { Good }\end{array}$ & $91-100$ & 0 & 0.00 & 2 & 7.41 & 0 & 0.00 & 1 & 4.17 \\
\hline Good & $76-90$ & 0 & 0.00 & 14 & 51.85 & 1 & 4.17 & 8 & 33.33 \\
\hline Average & $61-75$ & 9 & 33.33 & 8 & 29.63 & 12 & 50.00 & 11 & 45.83 \\
\hline Poor & $51-60$ & 13 & 48.15 & 3 & 11.11 & 10 & 41.67 & 4 & 16.67 \\
\hline $\begin{array}{l}\text { Very } \\
\text { Poor }\end{array}$ & $\leq 50$ & 5 & 18.52 & 0 & 0.00 & 1 & 4.17 & 0 & 0.00 \\
\hline \begin{tabular}{l} 
Total \\
\hline
\end{tabular} & & 27 & 100 & 27 & 100 & 24 & 100 & 24 & 100 \\
\hline
\end{tabular}

The comparison between experimental group and control group in the pretest result showed that there was significant difference of both groups in writing ability. It was proved by the result pre-test in both groups that most of students (12 or 50\%) in control group achieve 'average' category while 'poor' category was dominated in experimental group where it was attained by 13 or $48.15 \%$ students.

The post-test score in experimental and control group, however, showed that there was significant difference in the post-test result of both groups. Most of the students of experimental group namely 14 students or $51.85 \%$ achieved good category; while in the control group, most of the students (11 or $45.83 \%$ ) were categorized as 'average'. 
The comparison between the student's scores of pre-test in experimental and control group

The following table is the result of the students' score of the pre-test for experiment and control group. The table shows the different score on minimum, maximum, mean and standard deviation of both groups.

Table 3

The Minimum, Maximum, Mean and Standard Deviation of Students' Pretest and Post-test on Experimental and Control Group

\begin{tabular}{|c|c|c|c|c|c|}
\hline \multirow{2}{*}{ Group } & $\mathrm{N}$ & $\begin{array}{c}\text { Minimum } \\
\text { Score }\end{array}$ & $\begin{array}{c}\text { Maximum } \\
\text { Score }\end{array}$ & $\begin{array}{c}\text { Minimum } \\
\text { Score }\end{array}$ & $\begin{array}{c}\text { Maximum } \\
\text { Score }\end{array}$ \\
\hline $\begin{array}{c}\text { Experimental } \\
\text { Group }\end{array}$ & 27 & 40.00 & 70.00 & 58.00 & 94.00 \\
\hline $\begin{array}{c}\text { Control } \\
\text { Group }\end{array}$ & 24 & 45.00 & 78.00 & 56.00 & 91.00 \\
\hline Total Score & 51 & 40.00 & 78.00 & 56.00 & 94.00 \\
\hline
\end{tabular}

The data in table 3 shows that the minimum score of pre-test of the experimental group was 40 which was 'very poor' category, while the maximum score was 70 which was categorized as 'average'. By contrast, the minimum score of pre-test of the control group was 45 which was categorized as 'very poor' category while the maximum score was 78 which categorized as 'good'. It can be summarized that the minimum score of pretest is gained by the student of the experimental group while the maximum score is gained by the control group student. In line with this, the researchers can conclude that the baseline knowledge in the writing ability of control group students is higher than the experimental group.

Therefore, the minimum score of post-test of the experimental group was 58 which was classified as 'poor' category while the maximum score was 94 which categorized as 'very good'. It means that most of the students of the experimental group were in 'the safe point'. They were in 'average' category. The minimum score of control group' post-test was 56 which was categorized as 'poor' category while the maximum score was 91 which categorized as 'very good'. To sum up, the minimum score of post-test is gained by the student of control group while the maximum score is attained by the experimental group student. Although both of experimental and control group attained the score which was categorized as 'average', but the result of post-test in the experimental group was higher than the control group. It proves that the treatment by using Macromedia Flash Animation enhanced students' English writing skill. 


\section{Pair-test}

In the tables below, the researchers presents the difference of the students' writing ability before treatment and after treatment (pre-test and post-test) in the experimental group. This pair sample test was used to find out whether there was an improvement of the students condition before and after being taught by using Macromedia flash animation. The results were shown by the paired T-test or dependent T-test as follows:

Table 4

The Pair Sample Statistic of Experimental Group

\begin{tabular}{|c|c|c|c|}
\hline & Mean & N & Std. Deviation \\
\hline Pre-test & 55.41 & 27 & 7.66 \\
\hline Post-test & 73.93 & 27 & 9.07 \\
\hline
\end{tabular}

Refering to table 4, the mean score of the pre-test was 55.41 while the mean score of post-test was 73.93. The mean score of post-test was higher (18.52) than the pre-test. It indicated that the use of Macromedia Flash Animation significantly improves the students' writing skill of descriptive text.

In the line with the previous table, the following table also used to see the difference of pre-test and post-test in the experimental group.

Table 5

The Pair Sample Test of Experimental Group

\begin{tabular}{|c|c|c|c|c|c|c|}
\hline & \multicolumn{3}{|c|}{ Paired Differences } & \multirow{2}{*}{ T } & df & $\begin{array}{c}\text { Sig. } \\
\text { (2-tailed) }\end{array}$ \\
\cline { 2 - 5 } & Mean & $\begin{array}{c}\text { Std. } \\
\text { Deviation }\end{array}$ & $\begin{array}{c}\text { Std. Error } \\
\text { Mean }\end{array}$ & & & \\
\hline $\begin{array}{c}\text { Pretest } \\
\text { and } \\
\text { Posttest }\end{array}$ & -18.52 & 7.62 & 1.47 & $\begin{array}{c}- \\
\text { Pon }\end{array}$ & 26 & .000 \\
\hline
\end{tabular}

Refering to table 5 the mean score of the pre-test was 55.41 while the mean score of post-test was 73.93. The mean score of post-test was higher (18.52) than the pre-test. Therefore, the data on table 4.8 shows that the sig. 2 tailed or probability value of pre-test and post-test was .000 , it was lower than alpha $\alpha 0.05$ which indicated there is significant different between the score of pre-test and post-test. It meant that the writing skill of experimental group students after treatment was effective at 5\% significance level which indicated statistically improved. Thus, the alternative hypothesis (ha) was accepted and, of course, the null hypothesis (H0) was rejected. There was statistically significant different between the condition before and after the treatment. Then, it is concluded that the use of Macromedia Flash Animation is able to give a significantly greater contribution to enhancing students' English writing skill of descriptive text. 
56| ELT Worldwide Vol. 2 No. 2 October 2015

\section{The Analysis Data of the Students' Interest}

The questionnaire was distributed to the students of experimental class after giving treatment in the aim to find out whether the students are interested in learning writing descriptive text by using Macromedia flash animation.

Based on the data analysis of the questionnaire items which referred to the data of the interest of the students on the percentage analysis, the researchers found that none of the students who states negative statement to the use of Macromedia flash animation. Only 1 students or $4 \%$ attained the score in interval 52-67 which categorized as 'moderate' classification then 16 or 59\% got 'interested' category and 10 of the students got 'strongly interested' category. The frequency and percentage of the students' questionnaire are shown in table 6 as follows:

Table 6

The Rate of Frequency and Percentage of Students' Interest

\begin{tabular}{|c|c|c|c|}
\hline Interval Score & Category & Frequency & Percentage \\
\hline $84-100$ & Strongly Interested & 10 & 37 \\
\hline $68-83$ & Interested & 16 & 59 \\
\hline $52-67$ & Moderate & 1 & 4 \\
\hline $36-51$ & Uninterested & 0 & 0 \\
\hline $20-35$ & Strongly Uninterested & 0 & 0 \\
\hline
\end{tabular}

Referred to the analysis of questionnaire in the table 6 that the most of students, in this case, 16 or $59 \%$ were in positive statements on interval 6883 which indicated as 'interested', thus it can be concluded that the use of Macromedia flash animation is interesting to the students in learning writing descriptive text.This supported by the table 7 as follows:

Table 7

The Mean Score of the Students' Interest

\begin{tabular}{|l|l|l|l|}
\hline & N & Sum & Mean \\
\hline Questionnaire & 27 & 2164 & 80.15 \\
\hline
\end{tabular}

Table 7 shows the score of the students' interest was 80.15 which was categorized as 'interested'. It means that most of the students have positive statements, they interested in the use of Macromedia flash animation. 
In other words, the use of animation movie is interesting to the students in learning writing of descriptive text at the seventh grade of SMP Yapis 1 Fakfak.

\section{The Correlation between Student's Interest and Writing Ability}

Correlations measure how variables are related, in this case, the researchers measured the variables of students' interest and students' writing ability by Bivariate Correlation with Pearson method which is known as Product Moment Pearson. The results were shown in table 8. as follows:

\section{Table 8}

The Correlation Coefficient between Students' Interest and Students' Writing ability

\begin{tabular}{|c|c|c|c|}
\hline & & $\begin{array}{l}\text { Students' } \\
\text { Interest }\end{array}$ & Writing Ability \\
\hline Students' & Pearson Correlation & 1 & $.891^{* *}$ \\
Interest & Sig. (2-tailed) & & .000 \\
& $\mathrm{~N}$ & 27 & 27 \\
\hline \multirow{3}{*}{ Writing Ability } & Pearson Correlation & $.891^{* *}$ & 1 \\
& Sig. (2-tailed) & .000 & \\
& $\mathrm{~N}$ & 27 & 27 \\
\hline
\end{tabular}

**. Correlation is significant at the 0.01 level (2-tailed).

Table 8 above shows that the Pearson's $r$ for correlation between students'interest and students' writing ability is 0.891 . This number stands at the range $0.70-0.90$ which means the correlation between variable $\mathrm{X}$ and variable $\mathrm{Y}$ is strong or high. This number is also very close to 1 . For this reason, the researchers could conclude that there is a strong relationship between interest and writing ability variables. The sig. ( 2 tailed) value is less than 0.05 indicated that there is a statistically significant correlation between the two variables. The Pearson's $r$ value of 0.891 was positive. The value is positive because SPSS did not put a negative sign in front of it. So, positive is the default. Because the data is positive, it can be stated that when the interest of students increases (the first variable), the students writing ability (the second variable) also increases. Overall, there was a strong, significant and positive correlation between interest writing ability. Increases in interest were correlated with increases in rating of writing ability.

Based on the results of the research which refers to the students' writing in the pre-test of both experimental and control group, the researchers analyzed it in term of the five components of writing namely content, organization, vocabulary, language use, and mechanics. Language use aspect is the most 
increase up to 6.22 points. Even though students got difficulties but this component proved that students' got fantastic score compare with another while 'mechanics' is the lowest score which only increased 0.70 points; The error of spelling in writing was found as its caused. Furthermore, from the researchers observation during the treatments that was conducted for six meetings in different topics of writing that provided with Macromedia flash animation, the students could improve their ability in express their ideas in sentences; they could catch the main ideas and organized it well; they able to use the suitable and correct words which related to the topic given; they did have difficulties to make well formed, word function, and pronounce; they use, punctuation, capitalization in their writing well, but unfortunately they weak in spelling their word well.

In line with that, after classifying the rate percentage and frequency of students' pre-test score in experimental and control group, the researchers found that the baseline knowledge in writing ability of control group students is higher than the experimental group. Thus, the researchers can conclude that there was significant difference of both groups in writing ability. The writing ability before treatment in the control group is better than in the experimental group. On the contrary, in pre-test, the description of the data collected through the test showed that the minimum score of post-test is gained by the student of control group while the maximum score is attained by the experimental group student. It indicated that most of the students both of experimental and control group attained the score which was categorized as 'average' which was meant after giving treatment, the result of post-test in experimental group was higher than control group although they did not significantly different. This is because the teacher of both the experimental and control group used ICT as the media in teaching. The difference here in experimental group teacher used Macromedia Flash Animation while in the control group teacher used power point. The material teaching which is made in Macromedia Flash Animation is supported with the most interesting picture, animation and speaker voice. They were arranged interactively and attractively. Multimedia based learning can certainly present a more interesting subject matter, not monotonous, and facilitate the delivery.

In teaching writing especially in the experimental group which was thought using Macromedia flash animation, the researchers treated students step by step based on the four main steps in writing. Those steps were also in line with the theory by Zemach and Rumisek (2008) which described six steps of writing process as components of four main steps, namely pre-writing, drafting, reviewing and revising, and rewriting. But before of all, they began with the introduction on the words usually used in a descriptive text or a related topic. There were many example and exercise contained in the teaching material, so the students could see the example and had the time to 
practice it. In sum, the researchers believe that teacher method in teaching and supported by attractive media and the material will bring a good contribution on students' improvement in writing. Therefore, based on the observation, the researchers found that the students were more enthusiastic and interested in the learning process at the class. They looked more comfortable in paying attention to what the teacher had taught through the Macromedia Flash Animation and enjoyed the atmosphere of learning in the classroom, so they were participation doing the task individually, paired, or in group.

Interest and writing ability have a strong relationship. It can be seen that interest has an important role in writing ability. In order to write more, it is needed to build the writing interest first. This is in line with the statement that someone's interest can be stimulated by a visual object such as a combination of visual and auditory like Macromedia flash animation. This means that there was a good applicable material in enhancing student's writing skill. When the interest of students increases, the students writing ability also increases. Overall, there was a strong, significant and positive correlation between interest writing ability. Increases in interest were correlated with increases in rating of writing ability.

\section{CONCLUSIONS AND SUGGESTIONS}

The research result indicates that the use of Macromedia Flash Animation is effective in enhancing the students' writing skill. In terms of the writing component, the result specifies that from the five components in writing namely content, organization, vocabulary, language, and mechanics, the 'language use' aspect revealed the highest improvement. Language use in writing means how well a writer or student uses correct language and point of grammar. While the mechanics was the lowest. It means that the students somehow need more time to practice their mechanics ability.

The findings also pointed out that the interest of the students in the use of Macromedia Flash Animation is high. This is in line with the statement that someone's interest can be stimulated by a visual object such as a combination of visual and auditory like Macromedia flash animation. This means that students found a good applicable material in enhancing student's writing skill.

Finally, the researchers concluded that the students' interest in the use of Macromedia Flash Animation has positive correlation with the students' writing ability. This implies that an attractive and interactive English process with the use of Macromedia Flash Animation brought positive contribution in enhancing students' writing skill. 
Based on the conclusion above, the researchers gives some suggestions as follows: (1) English teacher is expected to be more creative in choosing materials, the up to date topic or the new ways for the process of learning and teaching English to the students such as by using Macromedia Flash Animation in teaching writing. It can be an alternative ways in teaching English writing the students to develop their writing skill. (2) English teacher is suggested to encourage, give opportunities and keep motivate students to write. In getting a good writing, teacher is suggested to implement the step in writing process and also give more attention to the students on five components of writing continually, so that the students can compose and organize their writings perfectly.

\section{References}

Gay, L.R. (2006.) Educational Research, Competencies for Analysis and Application, Eight Edition. Columbus. Ohio: Pearson Merril Publishing.

Good, (1959.) The Dictionary of Education. New York: McGraw-Hill Book Company.

Heaton, J.B, (1995.) Writing English Language Test, London: Longman.

Hornby, A.S.et al. (2002.) The Advances Learner's Dictionary to Current English.Third Edition.London: Oxford University Press.

Hughes. (2008.) Arthur, Testing for Language Teachers Forth Edition, Edinburgh: Cambridge.

Kayaogluet al.( 2011.) A small-scale experimental study: using animations to learnvocabularyTOJET: The Turkish Online Journal of Educational Technology, 10 (2), 24-30. 
Kim, D., \& Gilman, D. A. (2008.) Effects of Text, Audio, and Graphic Aids in Multimedia Instruction for Vocabulary Learning.Journal of Educational Technology \& Society, 11 (3), 114-126.

Macromedia. (2005.) Macromedia Flash Player Penetration.Online (http://macromedia.com/software/playercencus/flashplayer/penetratio n.html. Retrieved on December 15 $5^{\text {th, }} 2014$.

Pun, M. (2013.) The Use of Multimedia Technology in English Language Teaching: A Global Perspective. International Journal of Interdisciplinary Studies, 1 (1).

Sugiono. (2011.) Statistika untuk Penelitian. Bandung: Alfabeta

Weigle, S. C. (2009.) Assessing Writing.Second Edition. Cambridge: Cambridge University Press.

Zemach, D.E. \& Rumisek, L.A. (2008).College Writing: from Paragraph to Essay Oxford: Macmillan Publisher Limited. 